\title{
Longitudinal study of the health of cotton workers
}

\author{
D Li, Y N Zhong, R Rylander, Q Y Ma, X Y Zhou
}

\begin{abstract}
Objectives-To follow up a group of newly employed workers in a cotton mill, and to report changes in symptoms over time.

Methods-A group of 110 mill workers at a cotton mill in Shijiazhuang, China, was investigated by questionnaire, skin testing, and spirometric measurements of airway responsiveness through forced expiratory volume in one second $\left(\mathrm{FEV}_{1}\right)$. The workers were examined before starting work, at 10 weeks, and at one year.

Results-Decreases in $\mathrm{FEV}_{1}$ over shifts were small at 10 weeks and one year, and slightly higher among people with skin reactions to cotton dust extracts. Airway responsiveness, defined as the average decrease in $\mathrm{FEV}_{1}$ after $1.25 \mathrm{mg}$ methacholine was increased at 10 weeks. It remained about the same after one year, except in the workers positive for the skin test, in whom it was further increased. Subjective symptoms of chest tightness and cough with phlegm increased progressively at 10 weeks and one year; nasal irritation remained unchanged and dry cough decreased between 10 weeks and one year.
\end{abstract}

Conclusion-The results suggest that the airway inflammation caused by cotton dust increases with increasing exposure time and that the changes are more notable in workers with reactivity to cotton dust extract.

(Occup Environ Med 1995;52:328-331)

Keywords: organic dust; cotton; endotoxin; atopy

Among the different diseases induced by organic dusts, byssinosis caused by cotton dust was one of the first to be described in detail. Epidemiological studies were undertaken after clinical descriptions of the disease in the 1800 s and early $1900 \mathrm{~s}^{12}$ and eventually the prevalence of the disease was described. ${ }^{3-5}$

Although some studies showed relatively good relations between the amount of airborne dust and prevalence of disease, it was rapidly found that the cotton fibre itself was not the causative agent. After searching for chemical agents in the plant, it became clear through studies in the 1970 s and 1980 s that endotoxin was closely related to the disease. ${ }^{6-8}$ Experiments with pure endotoxin in inhalation studies reproduced the acute symptoms seen after exposure to cotton dust. ${ }^{9}$

Most of the epidemiological and experi- mental studies reported have focussed on acute changes. The relation between these and the changes that occur after chronic exposure has not been clarified. This is necessary for proper protection and identification of people at risk.

Our study was undertaken to follow up a group of newly employed workers in a cotton mill over time, and to relate the presence of acute symptoms to changes that occur after several years of exposure. We report the results from follow up examinations at 10 weeks and one year after the start of work.

\section{Materials and methods SUBJECTS}

The subjects were selected from newly recruited workers at two cotton mills in Shijiazhuang, China. At the follow up studies, workers from one of the mills did not participate for practical reasons. This report deals only with people from the mill on which a follow up could be performed. None of the 19 workers who dropped out had a health problem, but three of them showed a positive skin test.

All the workers were enrolled in the cohort in 1990 and their ages at the time ranged from 17 to 21 except one 27 year old and one 16 year old.

The cohort was examined before starting work in the mills, at 10 weeks, and after one year. The first selection consisted of 129 and the final cohort of 110 workers. In all of the 22 smokers their consumption of cigarettes was less than 11 a day. Table 1 shows the breakdown for sex, age, smoking habits, atopy, and dropouts.

\section{EXPOSURE ASSESSMENT}

The type of cotton mill varied, with Chinese as well as foreign cotton being used. The exposure to dust and endotoxin was determined in the different work areas. Samples of airborne dust were taken with a vertical

Table 1 Characteristics of the cohort

\begin{tabular}{lr}
\hline Selection & 129 \\
Drop out & 19 \\
Studied & 110 \\
Sex: & \\
Men & 34 \\
Women & 76 \\
Smokers & 22 \\
Non-smokers & 88 \\
Atopy, skin test: & \\
$\quad+$ & 22 \\
- & 88 \\
\hline
\end{tabular}


elutriator. ${ }^{10}$ The amount of dust was determined by standard methods.

The amount of endotoxin on the filters was determined by shaking these in $10 \mathrm{ml}$ pyrogen free water for 10 minutes. The supernatant was diluted and the amount of endotoxin was determined with the chromogenic version of the Limulus assay. The amount of endotoxin was expressed as $\mu \mathrm{g} / \mathrm{m}^{3}$.

\section{HEALTH INVESTIGATIONS}

Questionnaires were used to assess general life history and previous disease, including the presence of allergy. Another questionnaire, based on the suggested standard questionnaire for organic dusts, ${ }^{11}$ was used to assess the presence of symptoms related to work at the two follow up examinations.

Skin tests were carried out to determine presence or absence of atopy. To prepare the extract of cotton dust, the fat free cotton dust was soaked in Coca's liquid for 24 hours after which the supernatant was recollected and filtered through a Seit filter to eliminate bacterial contamination. The solution was sealed in ampules for use and stored at $4^{\circ} \mathrm{C}$. The solution was diluted to $1: 100$ and $0 \cdot 1 \mathrm{ml}$ was injected into the skin of each worker's hand; normal saline was used as a negative control. Twenty minutes after the injection, redness and swelling with a diameter of $0.5 \mathrm{~cm}$ or over around the injected area was taken as a positive response. People with a positive skin test were defined as atopic.

Pulmonary function was determined with a $\mathrm{Hi}-298$ microspirometer (made in Japan) and the procedure was based mainly on the American Thoracic Society (ATS) standard recommendation. The standing position was acceptable and a nose clip was not used. The subjects were trained for the procedure by an experienced technician before measurement. A minimum of three acceptable forced vital capacity (FVC) manoeuvres were obtained for each measurement and the microspirometer automatically selected the best one for print-

Table 2 Exposure in cotton mill

\begin{tabular}{|c|c|c|c|}
\hline & $\begin{array}{l}\text { Filters } \\
(n)\end{array}$ & $\begin{array}{l}\text { Dust }\left(\mathrm{mg} / \mathrm{m}^{3}\right) \\
\text { mean }(S D)\end{array}$ & $\begin{array}{l}\text { Endotoxin } \\
\left(\mu g / m^{3}\right)\end{array}$ \\
\hline Blowing & 4 & $0.50(0.41-0.56)$ & 0.34 \\
\hline Carding & 6 & $2.01(0.38-6.69)$ & 1.73 \\
\hline Yarn & 10 & $0.32(0.12-0.78)$ & 0.32 \\
\hline Spinning & 6 & $0.20(0.10-0.25)$ & 0.04 \\
\hline Warping & 4 & $0.92(0.63-1.08)$ & 0.41 \\
\hline Weaving & 8 & $0.35(0.20-0.64)$ & 0.004 \\
\hline Modifying & 4 & $0.38(0.35-0.41)$ & 0.004 \\
\hline
\end{tabular}

Table 4 Average decrease in FEV, after $1.25 \mathrm{mg}$ methacholine

\begin{tabular}{|c|c|c|c|c|}
\hline & $n$ & $\begin{array}{l}\text { Before work } \\
(\%) \\
\text { mean (SD) }\end{array}$ & $\begin{array}{l}10 \text { weeks } \\
(\%) \\
\text { mean }(S D)\end{array}$ & $\begin{array}{l}1 \text { year }(\%) \\
\text { mean }(S D)\end{array}$ \\
\hline $\begin{array}{l}\text { All workers } \\
\text { Men } \\
\text { Women } \\
\text { Smokers } \\
\text { Non-smokers } \\
\text { Atopic } \\
\text { Non-atopic }\end{array}$ & $\begin{array}{r}110 \\
34 \\
76 \\
22 \\
88 \\
22 \\
88\end{array}$ & $\begin{array}{l}-3.5(7 \cdot 7) \\
-3.5(5 \cdot 7) \\
-3.6(8 \cdot 1) \\
-4 \cdot 2(6 \cdot 4) \\
-3.3(7 \cdot 4) \\
-4 \cdot 6(9 \cdot 0) \\
-3.3(6 \cdot 7)\end{array}$ & $\begin{array}{l}-5.8(7.5) \\
-5.7(4.8) \\
-5.9(8.9) \\
-6.5(5.7) \\
-5.6(7.9) \\
-5.2(6.3) \\
-6.0(7.7)\end{array}$ & $\begin{array}{l}-4.9(6 \cdot 1) \\
-4.8(5.9) \\
-4.9(6.2) \\
-6 \cdot 3(6.9) \\
-4.5(5 \cdot 7) \\
-8 \cdot 1(8 \cdot 6) \\
-4 \cdot 2(5 \cdot 3)\end{array}$ \\
\hline
\end{tabular}

ing out. Pulmonary function tests were performed before and after the workshift.

Metacholine provocation test to determine airway responsiveness was also performed after the workshift. The subjects inhaled normal saline as a baseline and then various concentrations of metacholine. The provocation test according to the method of Yan et $a l,{ }^{12}$ previously used in studies of the effect of organic dust, ${ }^{1314}$ was used and the results were expressed as the decrease of $\mathrm{FEV}_{1}$ at the highest dose of metacholine given minus the baseline (value of saline inhalation).

\section{Results}

EXPOSURE ASSESSMENT

Table 2 shows the results from the measurements of concentrations of dust and endotoxins at different work sites. The dust concentrations varied between 0.20 and 2.01 $\mathrm{mg} / \mathrm{m}^{3}$ with the highest concentration in the cardroom as expected. Endotoxin concentrations varied between 0.004 and $1.73 \mu \mathrm{g} / \mathrm{m}^{3}$ with the highest concentration in the cardroom and the lowest in the weaving department. The correlation between dust and endotoxin concentration was $r_{x y}=0.96$.

\section{PULMONARY FUNCTION}

Table 3 shows the results from the baseline pulmonary function measurements and the decrease in $\mathrm{FEV}_{1}$ over a shift. The changes were very small. A tendency was seen for the changes to be more pronounced at 10 weeks after the start of work than at one year, regardless of the group of workers. On both occasions, the most pronounced decreases over the shift were found in atopic workers.

AIRWAY RESPONSIVENESS

Table 4 shows the average decrease in $\mathrm{FEV}_{1}$ after methacholine challenge. In the group as a whole, there was a slightly larger decrease in

Table 3 Baseline spirometry ( $\mathrm{ml}$ ) and changes in FEV, over a shift (\%) during the follow up

\begin{tabular}{|c|c|c|c|c|c|c|}
\hline & \multirow[b]{2}{*}{$n$} & \multirow{2}{*}{$\begin{array}{l}\text { Before exposure } \\
\text { Baseline (ml) } \\
\text { mean }(S D)\end{array}$} & \multicolumn{2}{|l|}{10 weeks } & \multicolumn{2}{|l|}{1 year } \\
\hline & & & $\begin{array}{l}\text { Baseline }(m l) \\
\text { mean }(S D)\end{array}$ & $\begin{array}{l}\text { Change (\%) } \\
\text { mean }(S D)\end{array}$ & $\begin{array}{l}\text { Baseline }(m l) \\
\text { mean }(S D)\end{array}$ & $\begin{array}{l}\text { Change (\%) } \\
\text { mean }(S D)\end{array}$ \\
\hline $\begin{array}{l}\text { All workers } \\
\text { Men } \\
\text { Women } \\
\text { Smokers } \\
\text { Non-smokers } \\
\text { Atopic } \\
\text { Non-atopic }\end{array}$ & $\begin{array}{r}110 \\
34 \\
76 \\
22 \\
88 \\
22 \\
88\end{array}$ & $\begin{array}{l}2909 \cdot 36(538) \\
3591 \cdot 47(389) \\
2604 \cdot 21(277) \\
3466 \cdot 82(443) \\
2770 \cdot 00(471) \\
2729 \cdot 09(529) \\
2954 \cdot 43(556)\end{array}$ & $\begin{array}{l}2990 \cdot 73(513) \\
3609 \cdot 41(401) \\
2713 \cdot 95(248) \\
3463 \cdot 64(478) \\
2872 \cdot 50(452) \\
2940 \cdot 00(518) \\
3003 \cdot 41(514)\end{array}$ & $\begin{array}{l}-1.1(5.1) \\
-0.4(5.4) \\
-1.5(4.7) \\
-0.3(5.9) \\
-1.3(4.7) \\
-1.7(3.3) \\
-1.0(5.4)\end{array}$ & $\begin{array}{l}3044 \cdot 91(545) \\
3616 \cdot 47(423) \\
2782 \cdot 30(364) \\
3427 \cdot 27(458) \\
2947 \cdot 09(524) \\
3086 \cdot 00(540) \\
3035 \cdot 57(549)\end{array}$ & $\begin{array}{c}0.05(5.3) \\
0.74(5.8) \\
-0.4(4.9) \\
1.2(7.4) \\
-0.3(4.4) \\
-0.8(5.2) \\
0.3(5.4)\end{array}$ \\
\hline
\end{tabular}


$\mathrm{FEV}_{1}$ induced by methacholine at 10 weeks and one year than before work. Smokers had slightly larger decreases than non-smokers on all test occasions. There was also a small difference between workers with a positive skin test and those with a negative one, which was significant at one year.

Among the workers with a positive skin test, the decrease in $\mathrm{FEV}_{1}$ induced by methacholine at one year was larger than at 10 weeks $(-8 \cdot 1 \% \quad v-4 \cdot 2$, NS). The reaction pattern over time among men and women as well as smokers and non-smokers (fig 1) followed the pattern for the whole group. Table 5 shows the decrease in $\mathrm{FEV}_{1}$ induced by $F E V_{1}$ induced by methacholine among atopic and non-atopic workers after one year's work.
Figure 1 Decrease in
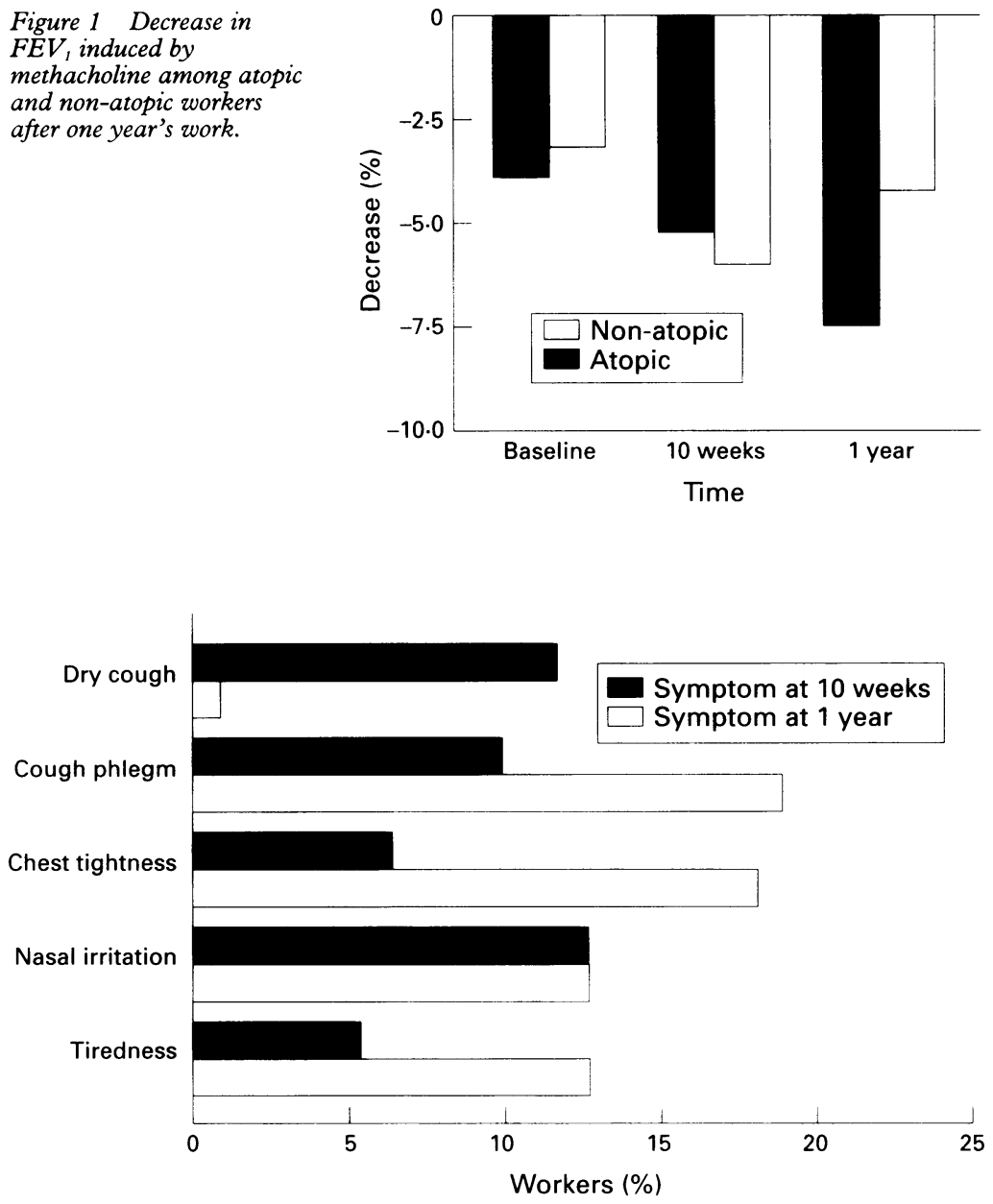

Figure 2 Proportion of workers with different symptoms at 10 weeks and one year after starting work. methacholine among non-atopic and atopic workers with reference to dust concentrations. It can be seen that the decrease was larger for atopic workers. No dose-response relation was found for this group. The group exposed to $0.20 \mathrm{mg}$ consisted only of six people.

\section{SYMPTOMS}

Before work, only a few workers reported general symptoms or symptoms from the respiratory tract. Figure 2 shows the symptoms reported by more than $5 \%$ of the workers at the two follow up examinations.

The proportion of workers who reported dry cough, cough with phlegm, chest tightness, nasal irritation, and tiredness at work increased significantly at 10 weeks compared with before work. Between 10 weeks and one year, the extent of dry cough decreased significantly and chest tightness increased significantly. Cough with phlegm and tiredness also increased, although without significance. The other symptoms were unchanged. Symptoms not reported in the table were wheezing chest, dyspnoea, shortness of breath and fever, which were only reported by one person or a few people.

\section{Discussion}

The study used standard techniques for the assessment of changes caused by exposure to cotton dust. As cotton dust causes an inflammation in the airways, ${ }^{14} 16$ measurements of inflammatory mediators or changes in inflammatory cell function such as neutrophil invasion into the airways or activation of $\mathrm{T}$ cells could also be used. Although such techniques have been used in experimental exposures, ${ }^{15}$ they are not, however, yet available for field studies.

The exposures in the mill studied show the same exposure pattern as earlier investigations, with high concentrations of endotoxin in the cardroom area and reduced contamination as the treatment process continued. The endotoxin concentrations at several of the work sites exceeded previous guidelines. ${ }^{16}$ Owing to the close relation between concentrations of dust and endotoxin, the relative importance of these agents could not be evaluated in this study. An increasing number of studies have shown that endotoxins are closely related to the range of effects studied in this investigation. ${ }^{6} 817$

Table 5 Decrease in FEV induced by methacholine in relation to dust concentrations at work

\begin{tabular}{|c|c|c|c|c|c|c|c|c|c|c|c|c|}
\hline \multirow{3}{*}{$\begin{array}{l}\text { Dust } \\
\text { concentrations } \\
\left(\mathrm{mg} / \mathrm{m}^{3}\right)\end{array}$} & \multicolumn{4}{|c|}{ Before work } & \multicolumn{4}{|c|}{10 weeks } & \multicolumn{4}{|c|}{1 year } \\
\hline & \multicolumn{2}{|c|}{ Non-atopic } & \multicolumn{2}{|c|}{ Atopic } & \multicolumn{2}{|c|}{ Non-atopic } & \multicolumn{2}{|c|}{ Atopic } & \multicolumn{2}{|c|}{ Non-atopic } & \multicolumn{2}{|c|}{ Atopic } \\
\hline & $n$ & $\triangle F E V_{1}$ & $n$ & $\triangle F E V_{1}$ & $n$ & $\triangle F E V$ & $n$ & $\triangle F E V_{I}$ & $n$ & $\triangle F E V_{1}$ & $n$ & $\triangle F E V_{i}$ \\
\hline Spinning $0 \cdot 20$ & 17 & $461 \cdot 1$ & 6 & $-186 \cdot 7$ & 17 & $-248 \cdot 8$ & 6 & $-133 \cdot 3$ & 17 & $-42 \cdot 5$ & 6 & $-280 \cdot 0$ \\
\hline Yarn 0.32 & 15 & $-140 \cdot 7$ & 3 & -93.3 & 15 & $-200 \cdot 0$ & 3 & $-80 \cdot 0$ & 15 & $-165 \cdot 7$ & 3 & $-400 \cdot 0$ \\
\hline Weaving 0.35 & 15 & $-88 \cdot 0$ & 5 & $-64 \cdot 0$ & 15 & $-170 \cdot 7$ & 5 & $-104 \cdot 0$ & 15 & $-181 \cdot 3$ & 5 & $-160 \cdot 0$ \\
\hline Modifying 0.38 & 17 & $-91 \cdot 8$ & 4 & $-386 \cdot 7$ & 17 & $-69 \cdot 4$ & 4 & $-270 \cdot 0$ & 17 & $-117 \cdot 7$ & 4 & $-170 \cdot 0$ \\
\hline Blowing 0.50 & 11 & $-160 \cdot 0$ & 0 & $\ldots$ & 11 & $-236 \cdot 4$ & 0 & - & 11 & $-149 \cdot 1$ & 0 & - \\
\hline Warping 0.92 & 10 & $-116 \cdot 0$ & 2 & $-66 \cdot 7$ & 10 & $-184 \cdot 0$ & 2 & -100 & 10 & $-160 \cdot 9$ & 2 & -100 \\
\hline Carding 2.01 & 3 & $-80 \cdot 0$ & 1 & $-40 \cdot 0$ & 3 & $-93 \cdot 3$ & 1 & $-\quad 0.0$ & 3 & $-40 \cdot 0$ & 1 & $-800 \cdot 0$ \\
\hline
\end{tabular}


The main finding in this study was the difference in the reaction patterns between workers who were identified as atopic or nonatopic with the skin test used. As all the workers had not previously been in extensive contact with cotton dust, the positive response of the atopic workers before starting work probably reflected a non-specific increase in reactivity rather that a reaction to cotton dust as such. The higher reactivity among atopic workers is in agreement with results from studies of acute exposure to cotton dust in which larger decreases in $\mathrm{FEV}_{1}$ after exposure to cotton dust were found among atopic workers. ${ }^{1318}$

The increase in airway responsiveness among atopic people between 10 weeks and one year, compared with the tendency to return to normal values in the non-atopic group, suggests that atopy is related to a larger potential for developing inflammation.

The return towards normal values for airway responsiveness in the non-atopic group at the one year follow up parallels the decrease in the extent of symptoms of throat irritation. Symptoms of nasal irritation and eye irritation also did not increase between 10 weeks and one year. This suggests that the symptoms that increased - cough with phlegm and chest tightness-are related to more advanced stages of inflammation in the airways, although further studies are needed to test this hypothesis.

The extent of some general symptomsheadache, vertigo, and tiredness-also increased between the follow up examinations. Although it could be easy to attribute this to general strain during work, observations from other organic dust areas suggest that systemic symptoms might develop. It has been shown that endotoxin when inhaled causes an increase in the secretion of adrenocorticotrophic hormone (ACTH). ${ }^{20}$ The subsequent effect on the central nervous system could be related to the subjective symptoms of fatigue and stress.

In summary, the results of this study suggest that people with a skin reaction to a crude extract of cotton dust are at risk of developing symptoms after prolonged exposure. The results also suggest differences in the reaction mechanisms involved, but results from further follow up studies on the same and other cohorts are needed before any final conclusions can be drawn.

This study was supported by the Swedish Work Environment Fund (contracts 91-0325 and 93-0030)

1 Prausnitz C. Investigations on respiratory dust disease in operatives in the cotton industry. London: His Majesty's operatives in the cotton industry. London: His Majesty's
Stationery Office, 1936, 60. (Medical Research Council, special report series, No 212 .)

2 Ritter WL, Nussbaum MA. Occupational illnesses in cotton industries. 1944;22:96-9.

3 Schilling RSF, Hughes JPW, Dingwall-Fordyce I, Gilson JC. An epidemiological study of byssinosis among Lancashire cotton workers. $B r \mathcal{F}$ Ind Med 1955;12: 217-27

4 Schilling RSF. Byssinosis in cotton and other textile workers. Lancet 1956;ii:261-5.

5 Berry G, McKerrow CB, Molyneux MKB, Rossiter CE, Tonbleson JBL. A study of the acute and chronic changes in ventilatory capacity of workers in Lancashire changes in ventilatory capacity of workers
cotton mills. Br $₹$ Ind Med 1973;30:25-36.

6 Haglind P, Rylander R. Exposure to cotton dust in an experimental cardroom. Br f Ind Med 1984;41:340-5.

7 Rylander R, Haglind P. Exposure of cotton workers in an experimental cardroom with reference to airborne endotoxins. Environ Health Perspect 1986;66:83-6.

8 Castellan RM, Olenchock SA, Kinsley KB, Hankinson JL. Inhaled endotoxin and decreased spirometric values: an exposure-response relation for cotton dust. $N \mathrm{Engl} F \mathrm{Med}$ 1987;317:605-10.

9 Rylander R, Bake B, Fischer JJ, Helander IM. Pulmonary function and symptoms after inhalation of endotoxin. Am Rev Respir Dis 1989;140:981-6.

10 Neefus JD, Lumsden JC, Jones LC. Cotton dust sampling. II Vertical elutriation. Am Ind Hyg Assoc $\mathcal{F}$ 1977;38: 394-400.

11 Rylander R, Peterson Y, Donham KJ. Questionnaire evaluating organic dust exposure. Am F Ind Med 1990;17: ating orgar $121-6$.

12 Yan K, Salome C, Woolcock AJ. Rapid method for measurements of bronchial responsiveness. Thorax 1983;38:760-5.

13 Jacobs RR, Boehlecke B, van Hage-Hamsten M, Rylander R. Bronchial reactivity, atopy and airway response to cotton dust. Am Rev Respir Dis 1993;148:19-24.

14 Rylander R, Bergström R. Bronchial reactivity among cotton workers. Ann Occup Hyg 1993;36:1-6.

15 Beijer L, Jacobs RR, Boehlecke B, Andersson B, Rylander R. Monocyte responsiveness and a $T$ cell subtype predict the effects induced by cotton dust exposure. American fournal of Respiratory Critical Care Medicine 1995; (in press).

16 Rylander $R$. The role of endotoxin for reactions after exposure to cotton dust. $A m \mathcal{F}$ Ind Med 1987;12:687-97.

17 Sigsgaard T, Pedersen OF, Juul S, Gravesen S Respiratory disorders and atopy in cotton wool and other textile mill workers in Denmark. Am $f$ Ind $\mathrm{Med}$ 1992;22:163-84.

18 Sepulveda M-J, Castellan RM, Hankinson JL, Cocke JB. Acute lung function response to cotton dust in atopic and non-atopic individuals. $B r F$ Ind Med 1984;41 487-91.

19 Pattermore PK, Asher MI, Harrison AC, Mitchell EA, Rea $\mathrm{HH}$, Stewart AW. The interrelationship among bronchial hyperresponsiveness, the diagnosis of asthma, and asthma symptoms. Am Rev Respir Dis 1990;142: and asth

20 Michel O, Duchateau J, Sergysels R. Effect of inhaled endotoxin on bronchial reactivity in asthmatic and normal subjects. $\mathcal{f}$ Appl Physiol 1989;66:1059-64.

21 Sandström T, Bjermer L, Rylander R. Lipopolysaccharide (LPS) inhalation in healthy subjects increases neutrophils, lymphocytes and fibronectin levels in bronchoalveolar lavage fluid. Eur Respir $\mathcal{F}$ 1992;5:992-6. 